A

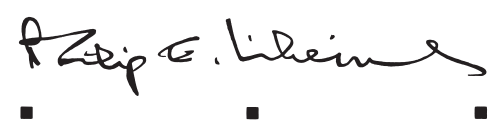

$\mathrm{B} \mathrm{O} \mathrm{O} \mathrm{K}$

The Philip E. Lilienthal imprint

honors special books

in commemoration of a man whose work

at University of California Press from 1954 to 1979

was marked by dedication to young authors

and to high standards in the field of Asian Studies.

Friends, family, authors, and foundations have together

endowed the Lilienthal Fund, which enables UC Press

to publish under this imprint selected books

in a way that reflects the taste and judgment

of a great and beloved editor. 
The publisher gratefully acknowledges the generous support of the Philip E. Lilienthal Asian Studies Endowment Fund of the University of California Press Foundation, which was established by a major gift from Sally Lilienthal. 
The Saint in the Banyan Tree 


\section{THE ANTHROPOLOGY OF CHRISTIANITY}

Edited by Joel Robbins

1. Christian Moderns: Freedom and Fetish in the Mission Encounter, by Webb Keane

2. A Problem of Presence: Beyond Scripture in an African Church, by Matthew Engelke

3. Reason to Believe: Cultural Agency in Latin American Evangelicalism, by David Smilde

4. Chanting Down the New Jerusalem: Calypso, Christianity, and Capitalism in the Caribbean, by Francio Guadeloupe

5. In God's Image: The Metaculture of Fijian Christianity, by Matt Tomlinson

6. Converting Words: Maya in the Age of the Cross, by William F. Hanks

7. City of God: Christian Citizenship in Postwar Guatemala, by Kevin O'Neill

8. Death in a Church of Life: Moral Passion during Botswana's Time of AIDS, by Frederick Klaits

9. Eastern Christians in Anthropological Perspective, edited by Chris Hann and Hermann Goltz

10. Studying Global Pentecostalism: Theories and Methods, by Allan Anderson, Michael Bergunder, Andre Droogers, and Cornelis van der Laan

11. Holy Hustlers, Schism, and Prophecy: Apostolic Reformation in Botswana, by Richard Werbner

12. Moral Ambition: Mobilization and Social Outreach in Evangelical Megachurches, by Omri Elisha

13. Spirits of Protestantism: Medicine, Healing, and Liberal Christianity, by Pamela E. Klassen 14. The Saint in the Banyan Tree: Christianity and Caste Society in India, by David Mosse 


\section{The Saint in the Banyan Tree}

Christianity and Caste Society in India

David Mosse

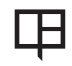

UNIVERSITY OF CALIFORNIA PRESS

Berkeley Los Angeles London 
University of California Press, one of the most distinguished university presses in the United States, enriches lives around the world by advancing scholarship in the humanities, social sciences, and natural sciences. Its activities are supported by the UC Press Foundation and by philanthropic contributions from individuals and institutions. For more information, visit www.ucpress.edu.

\section{University of California Press}

Berkeley and Los Angeles, California

University of California Press, Ltd.

London, England

(C) 2012 by The Regents of the University of California

Library of Congress Cataloging-in-Publication Data

Mosse, David.

The saint in the banyan tree : Christianity and caste society in India / David Mosse.

p. $\quad \mathrm{cm} .-$ (The anthropology of Christianity ; 14)

Includes bibliographical references (p. ) and index.

ISBN 978-0-520-25316-2 (cloth : alk. paper) — ISBN 978-0-520-27349-8

(pbk. : alk. paper) - ISBN 978-0-520-95397-o (ebook)

1. Christianity-India, South. 2. Tamil (Indic people)-Religion.

3. Christianity and other religions. 4. Social classes-India, South-

Religious aspects. 5. Caste-Religious aspects-Christianity. I. Title.

BR1156.154M67 2012

$275.4^{\prime} \mathrm{O} 808694-\mathrm{dc} 23$

2012021913

Manufactured in the United States of America

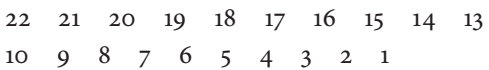

In keeping with a commitment to support environmentally responsible and sustainable printing practices, UC Press has printed this book on fifty-pound Enterprise, a 30 percent post-consumer-waste, recycled, deinked fiber that is processed chlorine-free. It is acid-free and meets all ANSI/NISO (z 39.48) requirements. 